REVIEW ARTICLE

住み慣れた家で死ぬということ

一あなたの家にかえろう, 在宅ホスピスケアの現場からー

櫻井 隆1

\title{
Supportive and Palliative Care at Home \\ -Improving Quality in End of Life Care Dying at Home-
}

Takashi Sakurail

${ }^{1}$ Sakurai Clinic, Japan.

ABSTRACT — Today most people fall into a deep sleep and never wake up in hospitals, where they are supposed to receive medical supports, instead of dying in their familiar and beloved home. Even those who choose facilities, such as nursing homes etc, as their last home, may have to move into hospitals before death for several days or even a few hours. Consequently, these terminal care is handled by only the hospital personnel with heavy responsibilities. As medical advances shorten hospital stays the site of death will more be the home. For those who want to go home at the end of their life, there will be more social supports and facilities in their community.

(JJLC. 2009;49:353-357)

KEY WORDS — Palliative care, Home care at home, Home care for the dying, Terminal care at home

要旨——ほとんどの人が住み慣れたところではなく, 病 院という本来医療を提供するはずの場で, 人生最期の時 を過ごして亡くなっていく．終の住処として入所したは ずの施設からも最後には追い出され病院へ救急搬送され てしまう。受け取る病院サイドも緩和ケアの延長線上に ある終末期医療への対応が負担となってしまう。病院， 医療依存型の往生際ではなく, 住み慣れた家であたりま
えに過ごして有終の美を飾る，そんな地域での死を支え る在宅ケア, 地域の看取りの文化を再構築できればいい. あなたもわたしも/仕事が終われば家へかえる/それと同 じょうに/人生という仕事が終わる時は/家にかえろう 索引用語——緩和ケア, 在宅ケア, 在宅死, 看取りの文 化

\section{はじめに}

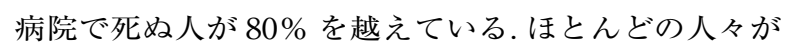
人生の最期の時を住み慣れた家ではなく病院で過ごすよ うになってしまった. 20 世紀, 生還, 延命を究極の目的, 勝利としてきた医療の現場ではその対極, 敗北として位 置づけられる死：そこでは“死”は本来あってはならな いもの，人目を避けるのが当然のように扱われてきた. 退院患者が堂々と病院の正面玄関から家にかえるのとは うらはらに, 敗者としての死者は, 地下の霊安室から通 じる裏口からひっそりと見送られる。すずての人々に
$100 \%$ ，必ず訪れる “死”。「生，老，病，死」という自然 な流れの最終段階であるはずの“死”は病院ではあまり 㴶迎されないものなのだろうか. 病院は本来, 治療する ところで死を看取る場所ではなかったはずである。そん な病院での死があたりまえになってしまった日本，日本 で病院死が在宅死を越えたのは 1970 年代, たった 30 年 前のことである.欧米でさえ扔よそ 30〜 40\% が自宅で死 妨とう 21 世紀の今, 世界中で日本の病院死だけが突出 して多い. 抢そらく人類数千年, 悠久の歴史の中で, 10

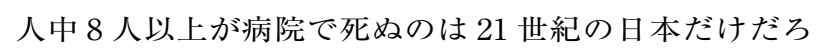

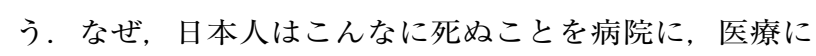


Table 1. Numbers of Patients Who Died at Home (Sakurai Clinic)

\begin{tabular}{|c|c|c|c|}
\hline \multicolumn{4}{|c|}{ Total 218 (Male $106 \quad$ Female 112) } \\
\hline Cancer patients & 167 & Non-cancer patients & 51 \\
\hline Lung & 32 & & \\
\hline Stomach & 27 & & \\
\hline Colon \& Rectal & 23 & & \\
\hline Liver & 19 & & \\
\hline Pancreas & 12 & & \\
\hline Breast & 10 & & \\
\hline Gynecologic & 9 & & \\
\hline Kidney \& Bladder & 7 & & \\
\hline Others & 28 & & \\
\hline
\end{tabular}

まかせて日常から隔離してしまったのだろうか？

20 世紀の後半, 科学の進歩はめざましく人々はさまざ まな恩恵をこうむった。医学も例外ではなく感染症を克 服し, 癌治療そして臓器移植, 遺伝子治療, 再生医療と もっと高く, 遠くへと命を伸ばすことばかり考えてきた. しかし結局最期に人は死ぬ, 着陸しなければならない, そのエンディングを優しく支えるという，ホスピスケア の概念がないがしろにされてきた.

「生, 老, 病, 死」のすべてを病院という箱の中におし 込めて医療で管理し, 日常から喪失させてしまった日本. 多くの人が死に逝く臨終の場を見たことがなく, 看取り の作法そのものが失われてしまった. 看取りの文化が 30 年というブランクを経て日常から消え去り, 病気や障害 があっても住み慣れた地域で，家で最期まで過ごして死 んで行くというあたりまえのことがとても難しくなっ た。そして今，“住み慣れた家で死ぬ”という本来はあた りまえのことを改めて見つめなおさなければならなく なってしまった.

\section{さくらいクリニックの在宅ケア}

在宅専門ではない, 外来一在宅ミックス型の診療所とし て，年間 20〜25 名を看取っている. 開業 16 年, 在宅ケ アを本格的に始めて 10 年でおよそ 200 名の患者を自宅 にて挸送りした，その $3 / 4$ が癌患者である。Table 1 にあるように，癌の種類はさまざまで在宅ケアの適否に は原発はあまり影響しないようである，専門医にとって は意外かもしれないが特に肺癌が在宅への移行が困難と いうわけではなく，統計上当然上位を占める．肺癌患者 は消化器系が保たれ比較的末期まで経口摂取が可能で, 呼吸困難を在宅酸素やオピオイド, 鎮痛補助剤, 軽度の 間欠的セデーションなどで乗り切れば在宅ケアでの看取 りは十分可能である。在宅ホスピスケアに際しては，医
師だけでなく訪問看護師, 歯科医, 理学, 作業療法士, 薬剂師, ケアマネージャー, ヘルパー, そしてボランティ アといったさまざまなケアスタッフの協力が不可欠なの はいうまでもない.さらにケアスタッフが本人，家族の セルフケアをサポートし, 取り巻く人達, 地域のケアの 力, 看取りの力を引き出すバックアップとして機能する ことで，過剩な負担を背負わずに在宅ホスピスケアを支 えることができる.

\section{BIO-PSYCHO-FAMILY-SOCIAL MODEL - 4 つの 視座での死一}

死を従来の生物一医学モデルだけでとらえている限り 在宅で死を看取る，ということ自体が不可能である，と いってもいいだろう．次元を広げたBIO-PSYCHOFAMILY-SOCIAL モデルで死をとらえることによっ て，我々医療者がかかわるべき範囲と限界がおのずと明 らかになっていくのではないだろうか，本来，死は医療 が抱えこむ事象ではないということを自ら知って，それ を知らしめることこそ，あたりまえの在宅死，死の日常 化への道となる。

\section{BIOLOGICAL}

人間の生物学的な死である。すなわち呼吸停止，心停 止, 瞳孔散大の死の 3 兆候を通過点とする生から死への 経過を意味する。医療が介入することによって極力避け ようとしてきた，というか先延ばしにしようと望んでき たのは，とりあえずこの生物学的な死であるといっても いいだろう。もちろん死亡確認, 死亡診断といった法的 な判断もこの生物学的な人間の死を基準としている. し かし, 脳死といった概念の導入で, この生物学的な人の 死の時間も摇れ動くこととなってしまった。ただいえる ことは，生から死へと移ろう中でどの瞬間を“死”とし て線引きするのかは社会的, 文化的な問題ではあっても, 少なくとも死んでいく本人やその大切な人達にとっては たいした問題ではないということである. 生から死への プロセスは時間をかけて訪れるもので, その過程に寄り 添うことにこそ味があるからである.

\section{PSYCHOLOGICAL}

従来の生物, 医学モデルを越えた領域での心理的な死, ある意味でコミュニケーションの終焉, といってもいい かもしれない。関係性の中で生きてきた人間としては他 者とのコミュニケーションが不可能となった時, その死 がすなわち, PSYCHO, 心理的な死ともいえるかもしれ ない.もちろんそれを包括し，昇華した形での死者との 対話, SPIRITUAL な関係は続いているとも考えられる.

\section{FAMILY}

家族，という血縁関係にとらわれた固定概念でなく， あなたの大切な人，という意味での FAMILYという広 
い視野でとらえたい．その家族にとっての死，別れとい う悲嘆をさりげなくサポートするのも我々ケアギバーの 大きな役割である．本来が家族という小宇宙の内部で自 己完結すべきことなのかもしれないが，崩壊しつつある 家族，地域でそれを支えることは困難になりつつある.

得てして我々ケアギバーは，家族を重視するあまり本 人をないがしろにしてしまいがちなこともある。さらに は家族が遺族となってもさりげなく支える姿勢が求めら れる.

\section{SOCIAL}

社会的な死, 社会的な存在としての一個人の死である. 葬送に関連する一連の儀式は遺族の気持ちの整理として のグリーフケアの一部であるとともに，日本人が人の死 に関して社会的に大きな意味を持たせていることがうか がえる（葬送関連行事に日本人がかける費用は平均 200 数十万ともいわれている. そのうち半分でも生前のケア にまわしてもらえば，と思わないでもないが).

一方で, 今の日本でその個人の死に逝く過程を支える システムが社会, 地域の中で実際に機能しているのか, という視点でも考えてみたい.すなわち『SOCIALCAPITAL』協同体として地域で本人の生から死への過 程，そして残された遺族達を支える，という看取りの文 化という視点である。医療, 病院に死をゆだねてしまっ た現代日本では看取りの文化は日常から, 地域から䘫失 してしまった。その看取りを社会の共同作業として地域 に，住み慣れた家に取り戻すには，日常生活の中から互 助作業としての支えあいの結果, 地域での看取りにつな がる，そんなコミュニティの再構築が必要だろう。 その コミュニティのサポートチームの一部として, 在宅ケア を支えるクリニックやナースステーション，ヘルパース テーションといったケアサポートチームが地域で活躍で きればいい.

\section{住み慣れた家で暮らす “生活者”として支える視点}

終末期の在宅ケアでは，医療系援助者の医師，看護師 が果たす役割が大きい，と皆が思いがちである。でも果 たしてそうであろうか.もちろん疼痛緩和など症状コン トロールと病状説明ができていることが最低条件で，そ れなくしては在宅ホスピスケアがなりたたない。それで は終末期のケアは医療系スタッフの独断場なのだろう か？日本のターミナルケアでは特に医師の果たす役割 が大きい. 日米の死生観の違いを研究する静岡がんセン ターの服部洋一氏はその著書「米国ホスピスのすべて〜 訪問ケアの新しいアプローチ〜」(ミネルヴァ書房) の中 で“日本のホスピスケアでは医師主導という性格が強く, 医師は病人の身体ケアを細部にわたって監督するだけで なく, 病人，家族の心理社会面を支える役割もになって
いる.この活躍の多面性は, 医師に大きな負担をかける だけでなく, 他の専門職の自立を妨げる要因にもなって いる. スタッフ全体にどうやって仕事と責任を割り当て るか，それに見合った信頼をどうやって育てるかが，今 後の大きな課題になるだろう”と日本の在宅ホスピスケ アの問題点を指摘している. 医療者は所詮, 医療の提供 者である．医療行為によって病人である患者の症状に対 してアプローチすることは可能だろう。しかし住み慣れ た家で暮らしているのは“患者”ではなく，たまたま病 気や障害を持った“生活者”である。白生活を支える のが医師だけではなく，すべてのケアギバーの役割とい える. そう考えると, 終末期のケアは特殊なものではな く, 生活者の日常をケアするという通常のサポートの延 長線上にあるといえる。できるだけ家族や周囲の人達, 地域のコミュニティで地域に生きる人の死をサポートで きるよう，黒子のように数歩さがってサポートできれば

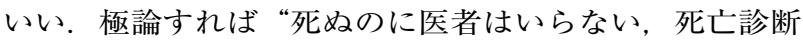
書だけあればいい”のかもしれない.

\section{在宅での看取りに関する緊急時の対応}

あまり過剩な延命処置を行わない在宅ホスピスケアの 場合, 基本的な症状コントロールが十分行われ, 予測さ れる症状の変化に対しての対応が本人, 家族に十分なさ れていれば, 急激な症状の変化で自宅では対応できない, という緊急事態に遭遇する確率は低い，急変時に家族や ケアスタッフがあわてて救急車を呼んでしまった，とい う事態を防ぐためにも，事前の症状に対する説明は必須 である. 患者に残された時間が, 月単位, 週単位, 日数 単位，そして時間単位と短くなっていくそれぞれの節目 で, 状況把握と対応を患者家族执よびケアスタッフ間で 共有しておく必要がある。予後予測は時として困難で思 わぬほど早く逝かれたり，逆に長引いて家族が疲れてし まうということもおこり得る。

在宅ホスピスケアの継続を困難にする一番の要因は, 患者, 家族の疲労と不安である. 症状の変化に際して不 安から過換気症候群になったり, せん妄状態の本人に対 して家族が冷静に対応できずパニック状態に陥ってしま うことがある. そこに同席するケアスタッフが動摇して しまうと，ますます患者，家族の不安をあ扔ってしまう。 病院と違って医師, 看護師が常時そばにいることのでき ない在宅では，家族の落ち着いた対応が患者自身の安心 につながる，そして最期の刻まで自宅で過ごすことを家 族が支えることができたなら, 別れの悲しさを超えてケ アできたことの達成感を得ることができるだろう． 


\section{最期の“とき”を支えるケア一家族が遺族に変わると き一}

そして最期の “とき”が訪れる. 予期せ㰠突然の別れ， 地震のように予期できない突然死と違って，癌など慢性 疾患による別れは台風のようにある程度予測が可能で前 もって準備して耐えることができる。しかし悲しみを分 散して予期しながら受け止めるか, 突然一気に襲ってき て打ちのめされるのか, という時間軸の違いはあっても, 結果として摇さぶられる感情の積算は同じなのかもしれ ない.

突然の事故死による別れの悲しみの総和 $=$

予期できる病による別れの悲しみの総和

感情のダメージを時間軸で分散しているだけかもしれ ないが, 予期悲嘆を経験するとその瞬間は台風の目の中 の無風状態のように，穏やかに別れを噛みしめることが 可能なようにも思う。 そのためには適切な台風の進路予 想が不可欠である. 死を身近に経験しなくなってしまっ た一般人に，死のプロセスを説明することが医師のとて も大切な仕事になってしまった，本来，死に逝く過程を 医師が説明する, ということ自体が奇妙なのだが. 本人, 家族のセルフケアが大切な在宅ホスピスケアに際して は, この死に逝く過程の説明と理解がなければ混乱，パ ニックを招いてしまう。この説明は時期が遅ければなん の意味もない. 台風が過ぎ去ってからの台風情報は不用 どころか，腹が立つだけだ．場合によっては家族だけで なく本人にも死に逝く過程を説明することもある．眠る ように楽に逝けると聞いてとても安心した，という反応 がほとんどだ。

\section{死へのプロセスの説明書}

\section{住み慣れた御自宅で御家族を看取られる方へ}

さまざまな御苦労を乗り越えて御自宅での療養をつづ けてこられましたが, 症状の変化から少しずつお別れの 時が近づいて来ていることが, 御家族の皆さまにも察し ていただけると思います。人生最後の時を住み慣れた御 自宅で, 御家族や御近所の方に囲まれてゆったりと過ご し有終の美を飾る，いろいろな思いが走馬灯のように駆 け巡ると同時に, これからの症状の変化にどのように対 処すればいいのか，いろいろ心配になる時期とも思いま す。できる限り落ち着いてゆったりとお別れできるよう に心の準備をしていただければ，と思います。

残された時間が週単位から日数単位になったと予想さ れる場合, 必要なら医師または看護師ができる限り毎日 おうかがいさせていただきます。御心配なことはなんで も遠慮なく相談してください.

\section{死が近づいてきた時の様子}

外の世界に対する関心がなくなり, 御自分の世界に 入っていかれるようになります.

新聞, 本, テレビなどに興味がなくなり，御一緒にお られる御家族以外の方との面会をあまり好まれなくなっ てきます。

うとうと寝ていることが多くなりますが, 呼ぶと目を あけて反応なさいます.

食事の量が減り，ほおや目などのやせが目立つように なります，

食物や水分が飲み込みにくくなりむせることがありま す. (プリンやゼリーなどつるっとしたものが飲み込みや すいこともあります)

わけのわからないことをしゃべったり，興奮したりす ることがあります.（せん妄）

便や尿を失敗することがあります.

口が乾燥して言葉が出にくくなり, 痰がきれにくくな ります. (水やぬらした綿棒などで口をしめらせると少し はしゃべられることもあります）

手足が冷たくなってきます。（血圧がさがるため）

いよいよ死が訪れ息をひきとられる時の様子

ほとんど眠っておられるようになってきます。そのう ち, 呼んでもさすっても反応がなく, ほとんど動かなく なります。

大きく呼吸をした後 10 ～15 秒止って, また呼吸をする 波のような息の仕方になります，肩や下顎を上下させて 浅い呼吸をするようになります. (少し苦しそうに見えま すが, ご本人はすでに意識がなく苦しみはないと思われ ます)

呼吸が止り，胸や顎の動きがなくなります。脈が触れ なくなり心臓が止ります.（医師, 看護師がそばにいない 場合はだいたいこの時間を亡くなられた時間として，記 憶にとどめておいてください）

手足が冷たくなり次第に固くなってきます.（室温など によりますが，急に固くなってしまうことはありません ので，あわてず，ゆっくり最期のお別れをなさってくだ さい) (どの時点で医師を呼ぶかは御家族の判断におまか せいたします)

\section{最期の“とき”のケアスタッフとしての心得}

亡くなっていく過程を事前に知り得ることで, 家族は 比較的冷静に対応し, 落ち着いて最期の別れの時を過ご すことができる．最期の臨終の時は親しい御家族や友人 だけで過ごすことを希望されるケースが多い. 一般に十 分ケアをしてかかわってきた家族は死を受容しており， 取り乱すことなく別れの時間をゆったり過ごすことがで きる．関わりが少なかったり，末期であることを十分理 
解していなかった親戚や知人の方がショックを受けるこ とが多い.日本人はいわゆる生物学的な死の瞬間，心停 止, 呼吸停止, 瞳孔散大の瞬間に立ち会うことを重要視 する傾向がある.「そんなことをすると親の死に目にあえ ない」というものである. 生から死への流れは瞬間では なく，長い時間の経過であり，その中で看取ることが大 切であることを説明しておいた方がいい．大切なのは死 瞬間に間に合うことだけではなく，それまでの過程の 中にこそある. 死の概念は時代や文化によっても異なる. 外界とのコミュニケーションがとれなくなった時点でそ の人はこの世からいなくなっている，という考元もある だろうし，心停止，呼吸停止しても，各々の細胞はすぐ には死なない。そしてその人が生きた，という事実，心 理的な存在感はその後も消えることはない.

援助者として臨終の場面に遭遇することもあるだろ う. その時は $2 \sim 3$ 歩さがって見守る姿勢が大切である. 医師は最期の場面に必ずしも同席する必要はない．家族 がゆっくり別れの時間を過ごした後で, 死亡確認と死後 の処置を行えばいい.

\section{× モ}

医師法 17 条, 20 条では継続診療中の患者が受診後 24 時間以内に診療中の疾患で死亡した場合については異常 がない限り, 改めて死後診察しなくても死亡診断書を交 付することを認めている.また受診後 24 時間を越えてい る場合であっても，診療に係る傷病で死亡したことが予 期できる場合はまず診察を行い，その上で生前に受診し ていた傷病が死因と判断できれば，死亡診断書を発行で きる．また「死亡したとき」は，死亡確認時刻ではなく， 死亡時刻を記入する（死亡診断書記入マニュアル；厚生 労働省).

\section{住み慣れた家で死ぬということ一死の日常化へ向け て一}

決して医療費削減のためではなく, 病床削減で溢れる
“死亡難民”を救うためではなく，在宅ケアをすすめる， というサービス提供側からのトップダウンの視点からだ けでなく、“あなたが願うなら”家でもだいじょうぶです よ，というボトムアップの視点からの在宅死があたりま えの選択肢となればいい.

病院に，医療に取り込まれてしまい，日常から喪失し た「生，老，病，死」を取り戻すのに住み慣れた家はとっ てもいい場所である。 そこでは去って逝く人とその人を 取り巻く家族, 大切な人, そして地域の人達が主役とな るべきである，我々ケアギバーはその人達を影で支える 存在とならねばならない。地域が，コミュニティが住み 慣れた家での看取りを取り戻せるように, SOCIALCAPITAL としての看取りの文化を再構築する，そんな 協同作業をやわらかく支えることができればいい，住み 慣れた家で, 地域で最期までと願う人を, 家族や大切な 人達が, ヘルパーが, ケアマネージャーが, 訪問看護師 が，近くの町医者がちょっとあわてたり，ほろっと涙を 流したり，でもやっぱりほほえんだりしながらふわっと 支える，そんな日を夢みて。

在宅死をサポートする冊子『あなたの家にかえろう』，扔かえ りなさいプロジェクト

「あなたが願うなら，家でもだいじょうぶですよ」というこ とを伝えるために多職種と市民から結成された複眼的視点を 持ったプロジェクトチームで，冊子『あなたの家にかえろう』 を制作，配布している.

詳しくはさくらいクリニックホームページまで.

http://www.reference.co.jp/sakurai/

おかえりなさいプロジェクト事務局

厂661-0043 尼崎市武庫元町 2 丁目 12-1

さくらいクリニック

Tel 06-6431-5555 Fax 06-6431-0666 